\title{
Chinese Merchants, Silver \\ Galleons, and Ethnic Violence in Spanish Manila, 1603-1686
}

DOI: $10.32870 /$ mycp.v12i36.330

Guillermo Ruiz-Stovel ${ }^{1}$

\section{Abstract}

$\mathrm{B}$ etween 1565 and 1815, silver-laden galleons made their way across the Pacific almost annually, carrying pieces-of-eight from the port of Acapulco and into the southern Chinese province of Fujian via the port of Manila, returning with raw and finished silk for Spanish American markets. With the arrival of the first galleons, Manila's Chinese community began to grow dramatically. By 1603 there were an estimated 30,000 Chinese and only a few hundred Spanish settlers. Manila may have been a Spanish possession, but for all practical purposes it was a Chinese town, inhabited not only by Chinese merchants but also by a skilled contingent of workers and artisans who kept the colony afloat. The Sangleyes, as the Manila Chinese were referred to in Spanish, were confined to a walled Chinese ghetto, known as the Parián, and banned from living in the fortified Spanish castle-town of Intramuros.

In 1603,1639 , and again in 1686 , Chinese uprisings rocked Manila. It is estimated that a total of over 40,000 Chinese migrants were massacred as a result of these revolts. Primary sources describe the existing tension between both Spaniards and Chinese: the exorbitant taxation and residential segregation of the Sangleyes; Spanish fears of being outnumbered and overrun in their own colony. This paper attempts to make sense of these events by taking the revolt of 1603 as a point of departure, followed by a brief discussion of

1. Profesor-investigador del Departamento de Estudios del Pacífico, Centro Universitario de Ciencias Sociales y Huanidades de la Universidad de Guadalajara. ORCID http:// orcid.org/0000-0001-6873-8704 
the underlying causes of ethnic violence in Spanish Manila. It then explores the background of Manila's economic and social structures in order to analyze the Sangley uprisings of the seventeenth century within the context of colonial Manila's role as the multiracial entrepôt of the trans-Pacific galleon economy.

It was in 1603 that the governor of Fujian, under imperial decree, dispatched the assistant magistrate of the port of Haicheng 海澄 to meet with the chieftain of the so-called Spanish "barbarians" (or xiao xiyang 小西洋). He sailed with a retinue of over a hundred men, and once he met with the governor of Manila, proceeded to inquire about a legendary mountain made of gold allegedly adjacent to Manila Bay, rumors of which had reached as far as the emperor.

The Spaniards were startled by this bizarre line of questioning. In the words of Antonio de Morga, an early chronicler of the Philippines:

The arriving of these mandarins seemed suspicious, and [it was thought] that they came with different intentions from that which they announced, because, for people of so much understanding as the Chinese possess, to say that the king sent them on such business seemed a fiction. ${ }^{2}$

The Spaniards interpreted the strange visit as a telltale sign of an imminent Chinese military attack on Manila. Documentary evidence shows that after the tragic experience of Spanish missionaries in Japan, Spanish colonists already harbored fears of a Japanese invasion. In the midst of this paranoia, the city's fortification system was strengthened, while warships and troops were rapidly gathered and put on alert. It was also believed (especially by the clergy) that the Manila Chinese were in on this alleged plot, and that under this war scenario, they would obviously fight on the side of their motherland. ${ }^{3}$

The Spaniards thus turned their fears into a self-fulfilling prophesy. As the Manila Chinese witnessed mounting war preparations, the sojourning

2. Quoted in Berthold Laufer, "The Relations of the Chinese to the Philippine Islands," Smithsonian Institutions, Miscellaneous Collections, Vol. L, No. 13 (1907), 267. Reprinted in: Dennis O. Flynn. Arturo Giráldez and James Sobredo, eds., European Entry into the Pacific: Spain and the Acapulco-Manila Galleons. The Pacific World, Vol. 4. (Aldershot: Variorum, 2001). Originally in Antonio de Morga, Sucesos de las islas Filipinas (Mexico, 1609).

3. This belief was not entirely without grounds or simply based on anti-Chinese sentiment. When the Chinese pirate Limahong attacked Manila in 1574, some Chinese migrants had joined forces with the attacker against the Spanish colonists. 
traders decided to flee, and the remaining settlers decided that it was better to have the advantage of being the first to strike, rather than take a defensive strategy. The date of this preemptive attack was set for October 4, when the Spaniards would be distracted by the feast of St Francis of Assissi. The planned insurrection was practically an open secret, but it was apparently a Tagalog woman married to a Chinese man that informed her father confessor of the plot. After this, open hostilities broke out. This was followed by 18 days of fierce combat, and Manila's Chinese quarter was bombarded from the San Gabriel bastion. Chinese casualties reached an estimated twenty-three thousand.

As for the envoys who had reached Manila in the quest for the Golden Mountain, they were less than positively depicted in the Ming Dynastic history in light of the massacre which they unknowingly unleashed:

Chang Yi [the leading envoy] and his accomplices deceived the Imperial Court and bred quarrel beyond the seas, in which they caused the death by sword of twenty thousand wealthy merchants. This is a terrible disgrace to our country [...] His head, hung on a pole shall be sent over to the chieftain of Luzon who dared kill the merchants [...] After that time the Chinese gradually flocked back to Manila; and the savages, seeing profit in the commerce with China, did not oppose them. ${ }^{4}$

Indeed, by 1604, the Sino-Philippine trade was again flourishing and the decimated population of the Chinese quarter, or Parián, was rapidly recovering.

\section{Understanding Chinese Revolts in Seventeenth-Century Manila}

So why did the riot of 1603 actually break out? The Spaniards clearly misread the intentions of the Chinese mission. But was this simply an example of crosscultural misunderstanding? Or was it a result of the measures of seclusion and control over the Chinese population that were already in place before the visit of the Chinese envoys? The discontent of the Manila Chinese may have been at a point where only a spark was needed to incite revolt. ${ }^{5}$ This first act of violence may have been just a tragedy waiting to happen.

4. Quoted in Laufer, “The Relations of the Chinese to the Philippine Islands”, 1907: 272.

5. Wickberg considers that the Spaniards resorted to three distinct methods of control over the Chinese population in Manila: a) costly residence licenses, high levels of taxation and arbi- 
In fact, prior to the three Chinese revolts of the 1600s, which are the focus of this paper, there was the precedent of a Chinese mutiny on a Spanish exploratory mission to the Moluccas, the legendary "Spice Islands." ${ }^{\text {Accord- }}$ ing to the Ming Annals,

In the 8th month of the 21st year of the period Wanli [1593], when the chieftain Don Perez Gomez das Mariñas undertook a raid on the Moluccas, he employed two hundred and fifty Chinese to assist him in the combat. It was Pan Howu who was their lieutenant. The savages lay down, drowsy in the daytime and commanded the Chinese to row the ship [...] Howu said, "Let us revolt and die in that way. Should we submit to being flogged or suffer any other such ignominous death? Should we not rather die in battle?

They proceeded to stab the then governor of Manila, and murder several other Spaniards while they were sleeping.

Yet Sino-Hispanic relations in the early colonial Philippines cannot be simply reduced to a tale of imperialist exploitation. It is estimated that by 1603, Chinese migrants outnumbered Spaniards 30 to 1 . Under these circumstances, the bargaining power of each of the parties and the interdependence between them makes this an especially complex case.

So what about the remaining two riots that occurred later in the 1600s? Did the uprisings of 1639 and 1686 share the same underlying causes as the bizarre incident of 1603 ? Were they also suddenly sparked by seemingly random events? What were the goals of the Chinese insurgents? Was there much planning behind them? Clearly, 30,000 Chinese could have annihilated a few hundred Spaniards if they had so desired. Living in the same city they could have certainly found access to the military technology that gave the Spaniards their edge.

By examining the continuities and discontinuities, similarities and differences, these three revolts may serve as a lens through which we can

trary levies; b) control over their site of residence, and c) the pressure to convert to Catholicism. Chinese converts could live outside the Parián and, unlike Chinese infidels, could even move to areas of the colony outside Manila. See Edgar Wickberg, The Chinese in Philippine life, 1850-1898, Yale University Press, New Haven and London, 1965: 9.

6. Manila served as the military base for a protracted and expensive eighty-year war that Spain fought (and eventually lost) against the Dutch over the Moluccas.

7. Quoted in Laufer, "The Relations of the Chinese to the Philippine Islands," 1907: 262. 
understand the power dynamics between the Spaniards and Chinese who inhabited Manila in the seventeenth century.

\section{A Bloody Prelude?}

For today's Chinese-Filipino community, this early history of bloodshed has been spun into a thread of continuous resistance, a long struggle by the Chinese community to assert themselves as Filipinos, to shed light on the fact that later generations of Chinese-Filipinos were key players in the formation of the Philippines as an independent and modern nation.

From a perspective contained within the modern boundaries of China as a nation-state, it is no surprise that maritime China has been considered peripheral in the context of an agrarian and continental empire. It is only through a broader perspective comprehending the entire rim of the South China Sea (or Nanyang 南洋) that the importance of South China's vast commercial network within the wider perspective of Asian regional history becomes evident. While commercial contacts (and the requisite tributary relationships) had existed with Southeast Asian polities as far back as the Tang, Song and Yuan dynasties, it would be until the eighteenth century, after the ban on maritime trade was officially lifted by the Qing in $1683,{ }^{8}$ that this maritime silk road would become a maritime highway, not only for the proverbial silk and spices, but for commodities such as gold and tin, as well as remittances and Chinese labor. It is this veritable explosion in the junk trade and the flow of Chinese population within the China Sea region that has led to the suggestion that the eighteenth century was indeed the Chinese century in the Nanyang. ${ }^{9}$ Anthony Reid in fact likens the longue durée relationship between China and Southeast Asia to an "erratic tap," with a series of spurts and trickles finally punctuated by a gush. ${ }^{10}$

8. A maritime ban or hai jin 海禁, outlawing private trade (i. e., any commercial activity outside the tribute system), had been in place (at least officially) from the very early years of the Ming dynasty and until 1567. The Manchus reinstated the ban once they took over China, especially due to Ming loyalist activities in the Southern coast. Coastal populations in Southern China were forced to retreat inland for decades before the lifting on the ban on private trade took place in 1683.

9. For a discussion see Leonard Blussé, "Chinese Century: The Eighteenth Century in the China Sea Region," Archipel, No. 58, 1999: 107-129.

10. See Anthony Reid, "Flows and Seepages in the Long-Term Chinese Interaction with Southeast Asia," ed. Anthony Reid, Sojourners and Settlers: Histories of Southeast Asia and the Chinese, Al- 
For today's Chinese-Filipino community, this early history of bloodshed has been spun into a thread of continuous resistance, a long struggle by the Chinese community to assert themselves as Filipinos, to shed light on the fact that later generations of ChineseFilipinos were key players in the formation of the Philippines as an independent and modern nation
The missing paper trail of this informal commercial empire contrasts starkly with the human trail left behind across Southeast Asia. Prior to the rise of Singapore as the prime Southeast Asian entrepôt, and en masse coolie migration to the region in the late nineteenth century, Chinese migration followed what Wang Gungwu has referred to as the basic huashang 華商 pattern. ${ }^{11}$ This consisted of overseas merchants, local traders and agents, as well as miners and other workers producing commodities for export to the Chinese market. And while some stayed behind and formed families (often second families) in Southeast Asia, the identity of the huashang was that of sojourner. ${ }^{12}$

The mass migration of Fujianese to Manila, more specifically individuals from the Minnan 閩南 area, commonly referred to as Hokkiens after their local dialect, was the most considerable spurt in this erratic human tap before the lifting of the maritime ban. It preceded the early Qing migrant "gush" by about a century. In light of this, the Manila riots make an interesting case of comparison with the somewhat less bloody sinophone Diaspora that was to follow.

len and Unwin, St. Leonards, NSw, 1996: 15-50.

11. Wang Gungwu, "Sojourning: The Chinese Experience in Southeast Asia," ed. Anthony Reid, Sojourners and Settlers: Histories of Southeast Asia and the Chinese, Allen and Unwin, St. Leonards, NSw, 1996: 4. Wang makes a clear distinction between the initial huashang pattern and the later mass migration of Chinese coolies or huagong 華工.

12. This can in a sense be understood as an extension of the long-established sojourning identity of merchants operating away from their hometown or province within China itself, as was the case of the prosperous Anhui merchants. 


\section{The Galleon Economy and the Manila-Fujian Nexus}

So why exactly were the Chinese in Manila, and why did they keep on coming back after their forerunners were massacred? Why didn't the Spaniards simply annihilate or expel them all? The simple reason behind this pact of convenience was non other than the Manila Galleon trade, which required cooperation between the two parties for the sake of profit. That the flow of silver and silk across the Pacific suffered only minor interruptions on account of piracy, sunken vessels, and armed conflict during its 244 years of existence is only part of what makes this trade route remarkable.

Most recently, the work by Flynn and Giraldez ${ }^{13}$ has emphasized the importance of this exchange for the development of global trade and revised the estimates of silver ${ }^{14}$ that flowed across the Pacific. Their work fits into a larger body of Asia-centric re-interpretations of the world economy in the Early Modern period ${ }^{15}$ and the relative role and status that China held within this system. ${ }^{16}$ In this way, previous scholarship on the "silverization" of the Chinese economy in the Ming-Qing era, ${ }^{17}$ has given way to more balanced treatments, the work by Von Glahn being the most comprehensive to date. ${ }^{18}$

13. Dennis O. Flynn and Arturo Giráldez. "Born with a 'Silver Spoon': World Trade's Origins in 1571," Journal of World History, Vol. 6, No. 2, 1995: 201-221; Flynn and Giraldez, "Cycles of Silver: Global Economic Unity through the Mid-Eighteenth Century," Journal of World History, Vol. 13, No. 2, 2002: 391-427.

14. The controversy surrounding the trans-Pacific flow of silver is quantitative in nature. Flynn and Giraldez have contested the "official" statistics of total silver that galleons transported as recorded in Spain's General Archive of the Indies and compiled in Pierre Chaunu, Les Philippines et le Pacifique des Ibériques (XVIe, XVIIe, XVIIIe siècles); introduction méthodologique et indices d'activité. (Paris: S. E. V. P. E. N., 1960). While it is generally accepted that there was significant underreporting due to smuggling, the argument has also been made that Flynn and Giraldez's new estimates may actually overestimate the total silver freight.

15. See Andre Gunder Frank, ReOrient: Global Economy in the Asian Age, University of California Press, Berkeley, CA, 1998, among others.

16. Refer to Kenneth Pomeranz, The Great Divergence: China, Europe, and the Making of the Modern World Economy, Princeton University Press, Princeton and Oxford, 2000; R. Bin Wong, China Transformed: Historical Change and the Limits of European Experience Cornell University Press, Ithaca and London, 1997.

17. William Atwell, "International Bullion Flows and the Chinese Economy," Past and Present, No. 95, 1977: 68-90.

18. Richard Von Glahn, Fountain of Fortune: Money and Monetary Policy in China, 1000-1700, University of California Press, Berkeley, 1996; "Myth and Reality of China's Seventeenth-Century Monetary Crisis," The Journal of Economic History Vol. 56, No. 2, 1996: 429-454; "Money Use in China and Changing Patterns of Global Trade in Monetary Metals, 1500-1800," eds. Flynn, 
By the time the Spaniards founded Manila in 1571, what von Glahn has called China's "Silver Century" (going from 1550 to 1650) was well under way. The Single-Whip Tax Reforms of 1570 marked the final step (and official recognition) of a long market-led "silverization" of the Ming economy. The counterproductive and hard-to-enforce Ming ban on maritime trade had finally been lifted in 1567, ${ }^{19}$ though Japanese silver had been flowing into China since the 1530s through several channels: initially via Korea and the Ryukyus, and later through illegal Chinese junk trade and Portuguese triangulation through Macao.

From the start, the early "silver years" of the Manila trade were closely tied to the rising fortunes of Fujian's Zhangzhou prefecture, the point of entry for Manila galleon silver into China. A bustling community of Hokkien Chinese soon thrived in Manila. However, as we well know, relations between the Spaniards and this network of merchants were not trouble free. The Spaniards' relations with other maritime powers on the China coast were also strained during this early period, particularly as the Spaniards tried to expand their Asian domains. The Spanish initiative to create the settlement of El Pinal (or "The Pine Grove") at the mouth of the Pearl River in 1598 failed largely due to Portuguese initiative to keep competition out of their market. The Spanish settlement founded on Taiwan in 1626 was slightly more successful, but in 1642, the Dutch, who were at war with the Spaniards over the Moluccas from 1606 to 1683, successfully expelled them, and (though temporarily) took over the island.

These early years also saw a trend towards more restricted trade. Initially, there was no limitation on the number of galleons sailing each year. The trade was also open to the Viceroyalty of Peru. Starting in 1593, the Spanish crown, prompted by the Seville merchants who controlled the trans-Atlantic trade, limited the trade to two galleons a year. In 1587 (and again in 1595), Peru was also banned from trading in Acapulco and purchasing the wares of the nao de China (as the Galleon was referred to in Spanish America).

Dennis O., Arturo Giráldez, and Richard von Glahn, Global Connections and Monetary History, 1470-1800, Ashgate, London, 2003.

19. Refer to note 6 . 


\section{The Players}

With a clearer understanding of the motives for Chinese and Spanish cohabitation in Manila, we can proceed to inspect each of the involved parties more clearly. ${ }^{20}$

First, we have the Filipinos, who seem to be absent from all of the accounts of the Chinese uprisings. To found Manila, the conquistador López de Legazpi basically evicted the inhabitants of the Tagalog village of Maynilad, a Muslim settlement that fell within what historians of Southeast Asia call a "power mandala," specifically that of the Sultanate of Brunei.

The Spaniards referred to the natives of the Philippines, whether they be Tagalogs, Cebuanos, Ilocanos, etc., simply as indios, the same nondescript and geographically incorrect term they used for the conquered peoples of Spanish America. And while, aside from Muslim resistance in the southern islands, the Filipinos were for the greatest part being passively converted en masse to Catholicism, they were far from "noble savages." It was after all native Filipinos that had murdered Magellan during his circumnavigation, and their hostility was one of the reasons why the Spaniards took over forty years to found a successful colony on the archipelago.

Where were the native Filipinos during the seventeenth-century riots? Did they stand by the sidelines? If so, what side did they cheer for? Or were they active participants? Precisely because secondary literature does not address this and there are few potential original sources, it is easy to forget that this was their land, that they were present throughout the hostilities, and that it was both the Spaniards and Chinese who were the outsiders.

The second group, the Chinese, had been in direct contact with the peoples of Luzon (the island on which Manila was founded) since as early as the Song dynasty. ${ }^{21}$ By the early Ming, Luzon was part of one of the two established routes of the junk trading system, that of the Eastern Sea, this included the

20. For the sake of simplicity and brevity, I have chosen to ignore Manila's Japanese merchant community as part of my analysis. The Japanese community reached its peak in 1620 with about 3,000 merchants. The community was located southeast of Intramuros in the suburb of Dilao, and was considered and ally by the Spaniards, largely due to the fact that most of these merchants were officially converts.

21. The island is referred to by Chinese sources as Lusong 「宋. 
Sulu kingdom, Borneo and the Moluccas. ${ }^{22}$ With the first decades of Spanish rule in Manila came tremendous economic opportunities for sea-faring Chinese, particularly those owning their own vessels. ${ }^{23}$

Once in Manila, Fujianese merchants and skilled workers were not allowed to live within the Spanish walled city, Intramuros, but were instead confined to the Chinese ghetto or Parián. The Spaniards referred to the Manila Chinese as sangleyes, a term allegedly derived from "seng-li," the word for "business" in the Hokkien dialect. For the Chinese, the Parián was known as the Kan, which has been taken to be Fujianese for "mountain torrent."

Zhangzhou 漳州 prefecture was swiftly drawn into the emerging trade connection with Manila. What had previously been a town dwarfed by Fuzhou and Quanzhou, suddenly became the hub of the Manila-Minnan trade. As the main goods on the westbound galleons, textiles were Zhangzhou's most important manufacture. Most of this was silk, although there was also cotton and other coarse cloths. There were certainly spillovers from this trade, and therefore distribution further inland of the silver from the galleons. Silk thread and cotton were both brought in from Zhejiang province. ${ }^{25}$

Zhanghzhou also produced lacquered boxes, fans, and porcelain that made their way overseas. As part of the Magellan Exchange, ${ }^{26}$ the peanut, sweet potato, and tobacco soon made their way into Zhangzhou (along with the boatloads of silver). ${ }^{27}$ After 1683, Amoy (Xiamen) began to replace Zhangzhou and its port of Haicheng as the center for Minnan-Manila commerce. As Hokkien Chinese made their way across the Nanyang, Amoy's prosperity surpassed that of Zhangzhou's glory days.

This brings us to the third group: the "Spanish imperialists." In 1565, the Spaniards had originally settled on the island of Cebu, seeing it as a base for the

22. That of the Western Sea covered present-day Vietnam, Cambodia and Thailand, as well as Melaka, Sumatra and Java. Details of theses routes are covered in the Dongxi yangkao 東西洋 考 (1617).

23. Wickberg, The Chinese in Philippine life, 1850-1898, 1965: 4.

24. Laufer, "The Relations of the Chinese to the Philippine Islands," 1907: 259.

25. Evelyn Rawski, Agricultural Change and the Peasant Economy of South China, Harvard University Press, Cambridge, MA, 1972: 74.

26. This is in the same vein as Alfred Crosby's concept of the Columbian Exchange, yet much more modest and with a lesser biological impact than the exchange between Europe and the Americas.

27. The people of Zhangzhou actually developed a strong fondness for tobacco from very early on and began growing it themselves. 
conquest of the Moluccas, but decided to move their base to the village of Maynilad after hearing that Chinese traders periodically visited this settlement.

In the Ming Dynastic History and the geographical treatise known as the Dongxi yangkao 東西洋考 (1617) Spaniards are referred to as Yusila (Yu-ssu-la or Yu-mi-la), which is taken to be an imitation of the sounds in las islas (or islands). ${ }^{28}$ This strangely enough did not refer at all to the Iberian peninsula or Spanish America, but to the Philippines themselves. Spaniards were also known as xiao xiyang (or "small Western Ocean"), though they were both often grouped together with the Portuguese under the popular term Folanji ("Franks"). ${ }^{29}$

\section{Playing Devil's Advocate}

But were the Spaniards really despicable villains? If they were so repressive, why didn't the Chinese leave once and for all? Why did they keep coming back after riots in which thousands of their countrymen were massacred?

The tacit agreement that had been reached with the Fujianese migrants was an oddity within the scope of Spanish colonialism. It was only a hundred and so years before the founding of Manila that the Spanish crown had expelled all Muslims and Jews from its kingdom. The mission of discovery and conquest that began in 1492 was a civilizing mission; at its heart was the conversion to Christianity of the natives of the new-found lands, who were to be zealously introduced to the mysteries of Catholicism. This was the time when the Spanish Inquisition mercilessly punished all suspected heretics.

The indios filipinos were to be converted whether they liked it or not (and those in the southern island of Mindanao were not afraid to resist by armed means). However, the Spaniards of Manila were willing to live side by side with the Chinese infidels, allowing them to live in a separate quarter just outside the Spanish inner city. This was a concession that would otherwise seem unimaginable. The Sangleyes were even granted a degree of autonomy. The Parián was under the jurisdiction of its own "mini-governor": the gobernadorcillo of the Sangleyes. The Parián was nonetheless an instrument of containment and control. And so to refer to the Parián as a Chinese quarter or a Chinese ghetto is not an arbitrary choice. It is enmeshed in the politics of history.

28. Laufer, "The Relations of the Chinese to the Philippine Islands," 1907: 249.

29. Ibid., 250. 
This is not to say that tensions did not exist between the Spaniards and what we can loosely refer to as their Chinese business partners. The Spaniards had failed to set up a trading station on the Chinese coast like the Portuguese had done with Macao. Also, unlike the Dutch, Portuguese, and later the English, they had no unified trade organization such as the Dutch voc, the Portuguese Estado da India, or the English East India Company. Under these circumstances, the Fujianese had a free hand on the Manila-Minnan leg of the trade route. The Spaniards thus held an unwavering belief (quite likely based on fact) that the Fujianese merchants were selling to them at inflated prices and were constantly looking for new ways to trick them. The phrase "trampas de China" or Chinese trickery was even coined, and eventually became a general term for unfair trade practices.

They cast the "Other" as ruthless and money-grubbing. According to the Agustinian friar, Sebastiao Manrique, who was in Manila from 1637 to 1638 : "[The Sangleyes] if possible, would go down to hell itself in order to bring new things to exchange." He even claims that they uttered the following motto in broken Spanish: "plata es sangre" (silver is blood). ${ }^{30}$

Manila's Spaniards were also facing tensions within the Spanish Empire itself. The Spanish crown saw the Manila-Acapulco trade as a drain on the Empire's silver bullion. For this reason it attempted to limit the amount of galleons that sailed each year to only two vessels. Truth be told, their main concern was that the profits of the galleon trade were being accrued by freetrading merchants in Manila and New Spain. This went completely contrary to the Empire's mercantilist policy of trans-Atlantic trade, where a cartel of merchants in Seville dominated all trade with the Spanish American colonies and extracted monopoly rents for the crown.

\section{The Uprising of 1639}

Having seen the flip side of the coin, we now turn to the Chinese uprising of 1639 .

30. Quoted in C. R. Boxer, Plata es Sangre: Sidelights on the Drain of Spanish-American Silver in the Far East, 1550-1700," Philippine Studies, No. 18, 1970: 463. Reprinted in Flynn, Dennis O., Arturo Giráldez and James Sobredo, eds. European Entry into the Pacific: Spain and the AcapulcoManila Galleons. [The Pacific World, Vol. 4, 2001]. Aldershot: Variorum. Originally in Sebastio Manrique, Itinerario de las Misiones que hizo el Padre Fr. Sebastian Manrique (Rome, 1649). 
Despite bans and caps on the number of Chinese in Manila, it is estimated that the Sangley population had by this time once again risen to about 30,000. The year 1639 was a particularly bad one for the Galleon trade. This translated into economic hardship for Chinese merchants and trickled down to the sector of skilled and unskilled workers. Consumer confidence levels were definitely at a low point.

Meanwhile, in nearby Laguna province, a group of Sangleyes who were being coerced into working crown lands decided to not only rebel, but to march into Manila. This was just the spark needed to start an insurrection in this climate of economic uncertainty. The Spaniards were determined to end the uprising and set the Parián on fire. Again, an estimated 20,000 Chinese died.

In 1643, in a document to the Spanish king regarding the insurrection, the authorities of the city offered the following explanation: "the lack of business occasioned the rising of the Sangleyes." ${ }^{31}$

\section{The Abortive Revolt of 1686}

Following the 1639 uprising, Manila entered a period of crisis. The Ming dynasty collapsed and Ming loyalists in Southern China led a campaign of resistance against the new Manchu regime. The resistance, and virtual rule over Fujian and Taiwan, by the Zheng family, particularly the notorious pirate-cum-hero Koxinga (Zheng Chenggong 鄭成功), kept the people of Manila in fear of an imminent invasion. Business was at a standstill. To make matters worse, upon Qing, the South China was forcefully evacuated until 1683, when the ban on maritime trade was finally re-lifted. The Manila-Minnan trade route would take years to recover.

Once more, it was in a climate of economic, and in this case, also politi$\mathrm{cal}$, uncertainty that the last of the three major revolts occurred. Just as the economy was slowly recovering, a small group of newly arrived Chinese men decided to rise up in protest against the Spanish policies towards the Chinese. It seems their aims weren't entirely genuine, since most of the Sangleyes did not join them. These men had grown up in an age of political instability and lawlessness in the South China coast, and it has been suggested that they were

31. William Schurz, The Manila Galleon, Dutton, New York, 1959 [1939]: 91. 
more interested in plunder than social justice. ${ }^{32}$ Casualties did not reach the levels of the previous two uprisings, but the Spaniards did take the opportunity to expel all but 6000 Sangleyes in order to ensure public safety in the colony.

The continued restrictions on the number of Chinese merchants imposed by the Spanish crown, together with the dramatic growth of the Chinese maritime network during Southeast Asia's "Chinese Century," rapidly saw the relative importance of the Manila trade eclipsed by new locations and opportunities throughout the 1700 s. $^{33}$

\section{Conclusion}

In conclusion, what these three seventeenth-century revolts teach us about Sino-Hispanic relations in this period is that, if anything, the two parties didn't understand, or for that matter, really like each other much. The pact of cohabitation kept in place during the almost 250 years of the galleon trade was clearly for the sake of profit. While the Sangleyes tolerated Spanish methods of control, the Spaniards tolerated inflated prices and the constant threat of being vastly outnumbered in their own colony. While 30,000 Fujianese may have well been able to expel or massacre a few hundred Spaniards had they so desired, without the Spanish colonists there would have been no galleon docking in Manila, no silver, and no lucrative Manila-Minnan trade.

In each of the instances in which the tacit pact of cohabitation was broken, it was not the result of a convoluted secret plot or of a protracted struggle of Sangley liberation. Though underlying tensions were a constant between these three revolts, the sparks that set each of these off appear to be random unconnected events. The Parián was a tinderbox. And when economic and political conditions became critical, all that was needed was a spark. my

32. Wickberg, The Chinese in Philippine life, 1850-1898, 1965: 11.

33. From the mid-1700s to the mid-1800s the Chinese population hovered around 5,000, quite far from its peak during the early 1600s. It would not be until the second half of the nineteenth century that there would be a veritable explosion in Chinese immigration. 


\section{References}

Amyot, Jacques, The Manila Chinese: familism in the Philippine environment, $2^{\text {nd }}$ ed., Institute of Philippine Culture/Ateneo de Manila University, Quezon City, 1973.

Atwell, William, "International Bullion Flows and the Chinese Economy," Past and Present, No. 95, 1977, pp. 68-90.

Bjork, Katharine, "The Link That Kept the Philippines Spanish: Mexican Merchant Interests and the Manila trade, 1571-1815," Journal of World History, Vol. 9, No. 1, 1998, pp. 25-50.

Blussé, Leonard, "Chinese Century: The Eighteenth Century in the China Sea Region," Archipel, No. 58, 1999, pp. 107-129.

Boxer, C. R., "Plata es Sangre: Sidelights on the Drain of Spanish-American Silver in the Far East, 1550-1700," Philippine Studies, No. 18, 1970, pp. 457-478. Reprinted in Flynn, Dennis O., Arturo Giráldez and James Sobredo (eds.), European Entry into the Pacific: Spain and the Acapulco-Manila Galleons [The Pacific World, Vol. 4.] Variorum, Aldershot, 2001.

Ch'en, Ching-ho, The Chinese community in the sixteenth century Philippines, Centre for East Asian Cultural Studies, Tokyo, 1968.

Chaudhuri, K. N., The English East India Company: the study of an early joint-stock company 1600-1640, Routledge/Thoemmes Press, New York, 1999.

Chaunu, Pierre, Les Philippines et le Pacifique des Ibériques (XVIe, XVIIe, XVIIIe siècles); introduction méthodologique et indices d'activité, S. E. V. P. E. N., Paris, 1960.

Deng Gang, Maritime Sector, Institutions, and Sea Power of Premodern China, Greenwood Press, London, 1999.

Flynn, Dennis O., and Arturo Giráldez, "Born with a 'Silver Spoon': World Trade's Origins in 1571," Journal of World History, Vol. 6, No. 2, 1995, pp. 201-221.

- - "Cycles of Silver: Global Economic Unity through the Mid-Eighteenth Century," Journal of World History, Vol. 3, No. 2, 2002, pp. 391-427.

Flynn, Dennis O., Arturo Giráldez, and James Sobredo (eds.), European Entry into the Pacific: Spain and the Acapulco-Manila Galleons. [The Pacific World, Vol. 4.] Variorum, Aldershot, 2001.

Flynn, Dennis O., Arturo Giráldez, and Richard von Glahn (eds.), Global Connections and Monetary History, 1470-1800, Ashgate, London, 2003. 
Flynn, Dennis O., Lionel Frost, and A. J. H. Latham (eds.), Pacific Centuries: Pacific and Pacific Rim History since the Sixteenth Century, Routledge, London, 1999.

Frank, Andre Gunder, ReOrient: Global Economy in the Asian Age, University of California Press, Berkeley, CA, 1998.

Laufer, Berthold, "The Relations of the Chinese to the Philippine Islands," Smithsonian Institutions, Miscellaneous Collections, Vol. L, No. 13, 1907, pp. 248-339. Reprinted in: Dennis O. Flynn, Arturo Giráldez, and James Sobredo (eds.), European Entry into the Pacific: Spain and the Acapulco-Manila Galleons. [The Pacific World, Vol. 4.] Variorum, Aldershot, 2001.

Ng, Chin-Keong, Trade and Society: The Amoy Network on the China Coast, 1683-1735, Singapore University Press, Singapore, 1983.

- - "The South Fukienese Junk Trade at Amoy from the 17th to the Early 19th Centuries," in E. B. Vermeer (ed.) Development and Decline of Fujian Province in the 17th and 18th Centuries, E. J. Brill, Leiden, 1990.

Pomeranz, Kenneth, The Great Divergence: China, Europe, and the Making of the Modern World Economy, Princeton University Press, Princeton and Oxford, 2000.

Rabinales, Patricio N., and Donna J. Amoroso, State and Society in the Philippines, Rowman and Littlefield, New York, 2005.

Rawski, Evelyn S., Agricultural Change and the Peasant Economy of South China, Harvard University Press, Cambridge, MA, 1972.

Reid, Anthony, "Flows and Seepages in the Long-Term Chinese Interaction with Southeast Asia," in Anthony Reid (ed.), Sojourners and Settlers: Histories of Southeast Asia and the Chinese, Allen and Unwin, St. Leonard's, NSw, 1996, pp. 15-50.

Schurz, William L., The Manila Galleon, Dutton, New York, 1939 [1959 reprint].

Souza, George Bryan, The Survival of Empire: Portuguese Trade and Society in China and the South China Sea, 1630-1754, Cambridge University Press, Cambridge, 1986.

Trocki, Carl A., "Chinese Pioneering in Eighteenth-Century Southeast Asia," in Anthony Reid (ed.), The Last Stand of Asian Autonomies: Responses to Modernity in the Diverse States of Southeast Asia and Korea, 1750-1900, MacMillan Press, London, 1997, pp. 27-84.

Valdés Lakowsky, Vera, De las minas al mar: historia de la plata mexicana en Asia, 1565-1834, FCE, Mexico City, 1987. 
Vermeer, E. B. (ed.), Development and Decline of Fujian Province in the 17 th and 18th Centuries, E. J. Brill, Leiden, 1990.

Von Glahn, Richard, Fountain of Fortune: Money and Monetary Policy in China, 1000-1700, University of California Press, Berkeley, 1996a.

-_, "Myth and Reality of China's Seventeenth-Century Monetary Crisis," The Journal of Economic History, Vol. 56, No. 2, 1996b. 429-454.

- - "Money Use in China and Changing Patterns of Global Trade in Monetary Metals, 1500-1800," in Dennis O. Flynn, Arturo Giráldez, and Richard von Glahn (eds.), Global Connections and Monetary History, 1470-1800, Ashgate, London, 2003.

Wang, Gungwu, "Sojourning: The Chinese Experience in Southeast Asia," in Anthony Reid (ed.), Sojourners and Settlers: Histories of Southeast Asia and the Chinese, Allen and Unwin, St. Leonards, NSw, 1996.

Wickberg, Edgar, The Chinese in Philippine life, 1850-1898, Yale University Press, New Haven and London, 1965.

Wills, John E., Pepper, Guns and Parleys: The Dutch East India Company and China, 1622-1681, Harvard University Press, Cambridge, MA, 1974.

Wilson, Andrew R., Ambition and Identity: Chinese Merchant Elites in Colonial Manila, 1880-1916, University of Hawaii's Press, Honolulu, 2004.

Wong, R. Bin, China Transformed: Historical Change and the Limits of European Experience, Cornell University Press, Ithaca and London, 1997.

Yuste, Carmen, El Comercio de Nueva España con Filipinas, 1590-1785, INAH, Mexico City, 1984. 